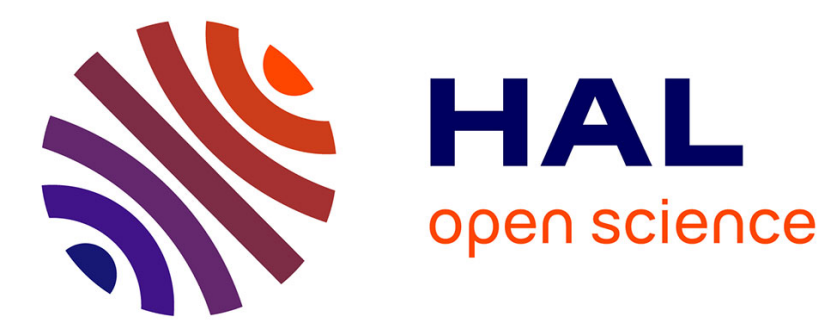

\title{
Does comparative advantage explain countries' diversification level?
}

\author{
Asier Minondo
}

\section{To cite this version:}

Asier Minondo. Does comparative advantage explain countries' diversification level?. Review of World Economics, 2011, 147 (3), pp.507-526. 10.1007/s10290-011-0097-7 . hal-00691340

\section{HAL Id: hal-00691340 \\ https://hal.science/hal-00691340}

Submitted on 26 Apr 2012

HAL is a multi-disciplinary open access archive for the deposit and dissemination of scientific research documents, whether they are published or not. The documents may come from teaching and research institutions in France or abroad, or from public or private research centers.
L'archive ouverte pluridisciplinaire HAL, est destinée au dépôt et à la diffusion de documents scientifiques de niveau recherche, publiés ou non, émanant des établissements d'enseignement et de recherche français ou étrangers, des laboratoires publics ou privés. 


\title{
Does comparative advantage explain countries' diversification level?
}

\author{
Asier Minondo \\ Deusto Business School \\ Camino de Mundaiz, 50; 20012 San Sebastián (Spain) \\ Tel.: +34 943 326600; Fax: +34943 273932 \\ E-mail: aminondo@deusto.es
}

\begin{abstract}
This paper analyses whether the products in which a country has comparative advantage can explain its exports' diversification level. We argue that specialisation endows countries with some specific skills and assets; in some cases those skills and assets can easily be redeployed in other products and facilitate diversification, whereas in other cases skills and assets are more difficult to redeploy and offer scant diversification possibilities. Based on countries' comparative advantage and an index of product proximity, we construct a metric for countries' diversification possibilities. Using non-parametric and parametric techniques, we show that this metric is a very strong and robust predictor of countries' actual diversification level, even when we control for differences in income across countries. These results point out that diversification may not be an automatic outcome of development.
\end{abstract}

JEL Code: F10

Keywords: product proximity, export diversification, international trade, comparative advantage

Acknowledgements: I am grateful to Cesar Hidalgo, the editor and two anonymous referees for many helpful suggestions. Any errors or omissions remain the author's own responsibility. 


\section{Introduction}

Export diversification has recently become a hot topic in the economic research agenda (Carrère et al. 2009; Newfarmer et al. 2009). There are old and new reasons that may explain this interest in export diversification. On the one hand, diversification is considered a key policy objective for countries specialised in natural resources (Sachs and Warner, 2001). On the other hand, countries seeking to accelerate economic growth through exports should determine whether diversification, rather than the intensive margin, is the best route to achieve this goal (Besedeš and Prusa, 2007). In addition to that, some models suggest that countries can increase their growth rate if they diversify into products where learning by doing is larger (Matsuyama, 1992) or into rich-country products (Hausmann et al., 2007). In any case, other models warn that diversification may be hampered due to the costs involved in discovering the new export products (Hausmann and Rodrik, 2003).

If exports diversification has a positive effect on economic growth, a relevant question is what determines its level. Some scholars show that diversification can be an outcome of the development process. Imbs and Wacziarg (2003), Koren and Tenreyro (2007), Cadot et al. (2007) and Klinger and Lederman (2009) find that countries grow through two stages of diversification. At low levels of income growth is accompanied by an increase in the level of diversification; however, once countries reach a certain level of income further growth is accompanied by re-concentration. In contrast, Parteka and Tamberi (2008) and De Benedictis et al. (2009) conclude that growth is always accompanied by an increase in the level of diversification. ${ }^{1}$

The contribution of this paper is to present and test an alternative explanation of the differences in export diversification across countries. We argue that countries' diversification levels may be determined by the products in which it has comparative advantage. The link between comparative advantage and diversification is established through the concept of product proximity developed by Hidalgo et al. (2007). These authors show that some products, such as electronics, tend to be exported along with a large range of different products; in contrast, other commodities, such as oil, tend to be exported alone. According to these authors, those differences are related to the skills and other assets, such as technology,

\footnotetext{
${ }^{1}$ It is important to indicate that there are differences across studies with respect to the diversification index used and its absolute or relative nature.
} 
capital or institutions, needed to produce each product. For example, the manufacturing of electronic products demand skills and assets that can easily be deployed in a large range of additional manufactures (e.g. to master the logistics of the components that are assembled in a factory); however, the extraction of oil demands skills and assets that are more difficult to redeploy in other products (e.g. to master the operation of a drilling rig). Due to these differences, countries that happen to develop comparative advantage in products that are close to other products can diversify more easily than countries that happen to develop comparative advantage in products that are in the periphery of the product space.

To test the validity of this explanation, we build an index of countries' diversification possibilities based on the products in which they have comparative advantage and the proximity of those products to the rest of commodities. Using non-parametric and parametric techniques, we show that this index is a very strong and robust predictor of countries' actual diversification levels, even when we control for differences in GDP per capita across countries. These results point out that countries' diversification levels might not be an automatic outcome of countries' development process. The conclusions of our paper are in line with a recent study by Hidalgo and Hausmann (2009), who using network techniques show that countries that have comparative advantage in products in which few countries also have comparative advantage are endowed with a larger set of capabilities; this larger set of capabilities, in turn, allows countries to export a larger set of products.

The rest of the paper is organised as follows. Section 2 explains in detail the relationship between countries' comparative advantage and their exports diversification level. Section 3 presents the empirical analyses and Section 4 concludes.

\section{The link between comparative advantage and diversification}

To establish the link between the products in which a country has comparative advantage and the diversification level we draw on the concept of product proximity developed by Hidalgo et al. (2007). These authors argue that several dimensions may influence the degree of relatedness between two products: similarities in the combination of productive factors, the characteristics of the technology used in production, the use of a specific component, the features of the final customers or the use of specific distribution channels. Due to the myriad 
of factors that may determine the relatedness between products, they use an outcome measure to calculate the degree of proximity between products. They argue that two products will be close to each other if countries tend to have revealed comparative advantage in both products. Based on this idea they calculate proximity $(\varphi)$ between product $i$ and product $j$ at year $t$ as:

$\varphi_{i j t}=\min P\left(x_{i, t} \mid x_{j, t}\right), P\left(x_{j, t} \mid x_{i, t}\right)$

where $P\left(x_{i, t} \mid x_{j, t}\right)$ is the conditional probability of having revealed comparative advantage in product $i$ given that the country has revealed comparative advantage in product $j$.

Based on this index and using network displaying techniques Hidalgo et al. (2007) are able to draw a product space map. This map shows that products are not evenly distributed: there are sections of the map with a high density of products, whereas other sections of the map are sparsely populated. Our argument is that these discontinuities in the product map are very important to determine countries' diversification opportunities. If a country happens to develop comparative advantage in a product which is close to a large number of other commodities, it will be easier for this country to diversify into new products. In contrast, if a country happens to develop comparative advantage in a very sparsely populated zone of the map, its diversification opportunities will be more scant. Hidalgo et al. (2007) provide evidence that diversification is governed by the relatedness between products. They show that countries tend to develop comparative advantage in those goods that are close to the products in which they have comparative advantage. According to this model, changes in a country's comparative advantage will lead to alterations in its diversification possibilities and, hence, on its exports diversification level.

The concept of product proximity can be rephrased in the framework of cones of diversification developed by Schott (2003) and Xian (2007). These authors argue that as countries accumulate capital (and other productive factors) they move to new diversification cones. In these models countries also shift from a product to a nearby product; however, in this case the closeness between products is determined by how they combine the productive factors in the production process. In Hidalgo et al. (2007) the proximity index encompasses not only the similarity in the ratio in which factors of production are combined, but also other features that may influence the relatedness between products. In addition to that, Hidalgo et 
al. (2007) argue that some cones of diversification may encompass a larger number of goods than others. Countries that end-up in diversification cones that cover a larger number of goods will be able to diversify into more products than countries that end-up in diversification cones with a smaller number of goods. ${ }^{2}$

To construct a metric for a country's diversification possibilities, we first, following Hausmann and Klinger (2007), calculate an index of product centrality, which is defined as the average proximity of a product to the rest of products:

Centrality $_{i t}=\frac{\sum_{j} \varphi_{i j t}}{J}$

where $J$ is the total amount of products. Second, based on this index, we calculate a country's diversification possibilities as the average centrality of products in which the country has revealed comparative advantage.

\section{Empirical analyses}

\subsection{Data}

We use data from the NBER World Trade Database to calculate product proximity indexes (Feenstra et al., 2005). This database offers data for SITC Rev. 2, 4-digit classification, that distinguishes 775 products. Countries' diversification possibilities are calculated for the 19802000 period. As we need to calculate countries' revealed comparative advantage to get countries' diversification possibilities, the sample of countries should be the same for the whole period. There are 91 countries that meet that criteria. ${ }^{3}$ Based on the same sample, product proximity indexes are calculated at the beginning of the period: 1980. To avoid reverse causality, we calculate a product proximity index set for each country. A country's product proximity index set is calculated by removing that country from the sample that is used to calculate product proximity indexes. Data on countries GDP per capita in constant

\footnotetext{
${ }^{2}$ As Cadot et al. (2007) point out, the diversification level may increase, temporarily, even when a country moves to a new diversification cone that encompasses the same number of goods. This may occur if incumbency advantages make the phasing-out of old products slower than the addition of new products to the export basket.

${ }^{3}$ We exclude from the sample countries with a population of less than 3 million.
} 
purchasing power parity (PPP) are obtained from the World Bank's World Development Indicators.

\subsection{Exports diversification index}

Following Cadot et al. (2007), the diversification of a country's export structure is calculated using a Theil index: ${ }^{4}$

$T=\frac{1}{J} \sum_{i=1}^{J} \frac{x_{i}}{\mu} \ln \left(\frac{x_{i}}{\mu}\right)$ where $\mu=\frac{\sum_{i=1}^{J} x_{i}}{J}$

where $J$ is the total number of products and $x_{i}$ denotes the amount of exports of product $i$. The Theil index is inversely related with a country's diversification level: the larger the index the lower the diversification level. In addition to the Theil index, in the parametric estimations, to asses the robustness of our results, we also use other concentration indexes, such as the Herfindahl index and the Gini coefficient.

\subsection{Non-parametric estimations}

In the first set of estimations we use non-parametric techniques to analyse the relationship between our relevant variables: diversification, countries' centrality and GDP per capita. The advantage of non-parametric estimations is that they do not impose any prior functional form on the estimated relationship. For our analyses we use a lowess smoothing function.

First, as in previous studies, we analyse the relationship between GDP per capita and diversification. ${ }^{5}$ Figure 1 presents the relationship between GDP per capita and the Theil index. As shown in the figure, we observe that the relationship between GDP per capita and concentration follows a convex curve: there is sharp reduction in concentration when GDP per capita rises from low income levels, but the slope becomes smoother when larger GDP per capita levels are reached. The lowest concentration level happens at around 24,000 PPP \$, similar to the turning-point level found by Cadot et al. (2007). From this GDP per capita onward there is almost a flat relationship between income and diversification. This result is

\footnotetext{
${ }^{4}$ The Theil index is derived from Shannon's measure of information entropy.

${ }^{5}$ Due its very large PPP GDP per capita, United Arab Emirates behaves as an outlier and, hence, is excluded from the sample.
} 
not in line with the re-concentration process found by Imbs and Wacziarg (2003), Koren and Tenreyro (2007), Klinger and Lederman (2009) and Cadot et al. (2007); however, it is in line with the results in Parteka and Tamberi (2008) and De Benedictis et al. (2009) who do not find either a two-stage process. ${ }^{6}$

Figure 2 presents the relationship between our index of countries' diversification possibilities, countries' centrality, and the Theil index. As expected, we find that countries with a larger centrality index have a lower concentration level. This result confirms that countries with revealed comparative advantage in goods that are close to a large number of other commodities are able to export a larger range of goods than countries that have revealed comparative advantage in goods that are in the periphery of the product space. To analyse whether the positive relationship between countries' centrality and diversification is governed by GDP per capita, Figure 3 presents the relationship between GDP per capita and centrality. We can observe that there is, in fact, a positive relationship between both variables. However, we can also see that there are large differences in the level of countries' centrality for the same GDP per capita level. To sum up, non-parametric analyses show that both GDP per capita and centrality may explain countries' diversification levels. Hence, to determine what is the relative contribution of both variables to countries' diversification the next section presents the results of parametric estimations.

\subsection{Parametric estimations}

Table 1 and Table 2 present the results of the parametric estimations. In Table 1, following the re-concentration hypothesis, we assume a non-monotonic and non-linear relationship between diversification and GDP per capita. In order to capture this non-monotonic and nonlinear relationship, following previous studies, we introduce GDP per capita and the square of GDP per capita as independent variables. In Table 2, we assume that there is a monotonic relationship between diversification and GDP per capita. In order to capture this monotonic relationship we introduce the inverse of the GDP per capita as independent variable. This functional form is non-linear, as in the previous case; however, contrary to the previous functional form, it is monotonic. For each specification, we estimate four different models. First, we pool all observations and estimate the model with simple OLS. Taking advantage of

\footnotetext{
${ }^{6}$ To analyse whether the differences in results were driven by the non-parametric technique used in the analyses, following these later authors, we also estimated a generalized additive regression model (GAM), with no changes in the shape of the fitted curves.
} 
the panel structure of our dataset, second, we estimate a between-effects model; third, a fixedeffects model and fourth, to control for the possible endogeneity between the dependent and independent variables, a GMM model. ${ }^{7}$ Finally, we estimate all the models with centrality as the only independent variable and, then, we introduce the GDP per capita coefficient, in its non-monotonic and monotonic specification, as an additional independent variable.

As there is much more variation in diversification across countries than within countries, the pooled OLS and the between-effects models have a much larger R-square than the fixedeffects model. We can observe that both in the non-monotonic (Table 1) and in the monotonic specification (Table 2), centrality has a negative and statistically significant coefficient in all models. These results point out that countries' diversification possibilities play a very strong role in determining countries' exports diversity. We can see, as well, that centrality has a negative coefficient and it is statistically significant even when we control for differences in GDP per capita across countries. In Table 1, we observe that GDP per capita has a negative coefficient and the square of GDP per capita has a positive coefficient, confirming the predictions of a non-monotonic relationship between income and diversification. However, GDP per capita and the square of GDP per capita are only statistically significant in the fixedeffects model. In the monotonic specification, the inverse of GDP per capita is always positive and statistically significant. As explained above, to control for endogeneity, in the last columns of Table 1 and Table 2 we estimate a GMM model. The (System) GMM model treats all covariates as potentially endogenous and include their lags and first-differences as instruments. We observe that in all specifications, centrality remains negative and statistically significant. Moreover, in all GMM estimations, we cannot reject the crucial assumption of no second-order correlation of the residuals.

To further analyse the robustness of our results we perform additional regressions analyses. First, previous studies, such as Parteka and Tamberi (2008) and Starosta de Waldemar (2010), show that country size influences countries' diversification possibilities. ${ }^{8}$ If economies of scale are prevalent, smaller countries will have less opportunities to develop a large range of industries. Table $3 \mathrm{a}$ and Table $3 \mathrm{~b}$ in the Appendix present the results of the estimations when we introduce a variable for country size. We use two variables to proxy country size: GDP

\footnotetext{
${ }^{7}$ We do not present the results for the random-effects model because the Hausmann test rejects the null hypothesis of no correlation between the independent variables and country random effects.

8 Other less time-variant variables that may also influence diversification possibilities, such as rent-seeking or geography, are control for in the fixed-effects model estimation.
} 
and population. As expected, both population and GDP coefficients are negative, confirming that larger countries have more diversification opportunities than smaller countries; however, the population coefficient is not statistically significant in the non-monotonic specification's between-effects model and the GDP coefficient is only statistically significant in the monotonic-specification's pooled OLS model. The centrality coefficient has the correct sign and remains statistically significant in all estimations.

Next, we perform the econometric analyses using alternative measures for export concentration: the Herfindahl index and the Gini coefficient. One limitation of these indexes is that they are bounded between zero and one. Moreover, as shown in Figures $4 \mathrm{a}$ and $4 \mathrm{~b}$, in our sample countries Herfindahl indexes are clustered around zero and Gini coefficients are clustered around one. As the censoring of data may lead to biased estimations, following Cadot et al. (2007), we also estimate the models using a logistic transformation of the Herfindahl and Gini coefficients. In the case of the Herfindahl index (Tables 4a and 4b in the Appendix), centrality has always a negative coefficient and is statistically significant. We can observe that estimations with the logistic transformation (Panel B) yield better results than estimations with the standard coefficient. First, the fit of the model is always larger with the logistic transformation, specially in the non-monotonic specification. Second, in the nonmonotonic specification the logistic transformation yield the expected coefficients on GDP per capita and the square of GDP per capita in all estimations.

When the Gini coefficient is used as the dependent variable, the centrality index has the correct sign in all estimations. However, it is statistically not significant in five of the seven estimations of the fixed-effects model with the standard coefficient (Table 5a and Table 5b in the Appendix - Panel A). This results might be explained by the large degree of observations that are clustered around the value 1 (Figure 4b). In fact, when we estimate the fixed-effects model with the logistic transformation the centrality coefficient is always negative and statistically significant. 


\section{Conclusions}

In this paper we show that the products in which a country has comparative advantage may play a very important role on countries' exports diversification level. We argue that countries that develop comparative advantage in commodities that demand skills and assets that can be easily redeploy in other products have more opportunities to diversify into new products than countries that develop comparative advantage in goods that demand skills and assets that are more difficult to redeploy. To test this hypothesis we calculate an index of countries diversification possibilities that combines countries' comparative advantage and proximity between products. Using non-parametric and parametric techniques we show that the diversification possibilities index is a strong predictor of countries actual diversification level, even when we control for differences in GDP per capita across countries. These results indicate that the products in which a country has comparative advantage play a very important role in explaining the level of export diversification; hence, export diversification might not be an automatic outcome of the process of development.

\section{References}

Besedeš, T. and Prusa, T.J. (2007). "The Role of Extensive and Intensive Margins and Export Growth", NBER Working Paper 13268, National Bureau of Economic Research, Cambridge, MA.

Cadot, O., Carrère, C. and Strauss-Kahn, V. (2007). "Export Diversification: What's Behind the Hump", CEPR Discussion Paper Series 6590, London: Centre for Economic Policy Research.

Carrère, C., Strauss-Kahn, V. and Cadot, O. (2009). "Trade Diversification, Income and Growth: What Do We Know?", CERDI Working Paper E 2009.31, Clermont-Ferrand: Centre d'Etudes et de Rechercher sur le Développement International.

De Benedictis, L., Gallegati, L. and Tamberi, M. (2009). "Overall trade specialization and economic development: countries diversify", Review of World Economics/Weltwirtschaftliches Archiv, 145, 1, 37-55.

Feenstra, R.C., Lipsey, R.E., Deng, H. Ma, A.C. y Mo, H. (2005). "World Trade Flows: 19622000", NBER Working Paper 11040, National Bureau of Economic Research, Cambridge, Massachusets.

Hausmann, R. and Klinger, B. (2007): “The Structure of the Product Space and the Evolution of Comparative Advantage", CID Working Paper 146, Center for International Development at Harvard University. 
Hausmann, R., Hwang, J, and Rodrik, D. (2007). "What You Export Matters", Journal of Economic Growth, 12, 1, 1-25.

Hausmann, R. and Rodrik, D. (2003). "Economic development as self discovery", Journal of Development Economics, 72, 2, 602-633.

Hidalgo, C.A. and Hausmann, R. (2009). "The building blocks of economic complexity", Proceedings of the National Academy of Sciences, 106, 26, 10570-10575.

Hidalgo, C.A., Klinger, B., Barabási, A.L. y Hausmann, R. (2007). "The Product Space Conditions the Development of Nations", Science, 317, 5837, 482-487.

Imbs, J. and Wacziarg, R. (2003). "Stages of Diversification", American Economic Review, 93, 1, 63-86.

Klinger, B. and Lederman, D. (2009). "Diversification, Innovation, and Imitation of the Global Technological Frontier", in Newfarmer, R., Shaw, W. and Walkenhorst, P. (eds.) Breaking into New Markets. Emerging Lessons for Export Diversification, The World Bank, Washington D.C.

Koren, M. and Tenreyro, S. (2007). "Volatility and Development", Quarterly Journal of Economics, 122, 1, 243-287.

Matsuyama, K. (1992). "Agricultural Productivity, Comparative Advantage and Economic Growth", Journal of Economic Theory, 58, 2, 317-334.

Newfarmer, R., Shaw, W. and Walkenhorst, P. (eds.) (2009). Breaking into New Markets. Emerging Lessons for Export Diversification, The World Bank, Washington D.C.

Parteka, A. and Tamberi, M. (2008). "Determinants of Export Diversification: An Empirical Investigation", Quaderni di Ricerca $n^{\circ} 327$, Università Politecnica delle Marche

Sachs, J.D. and Warner. A.M. (2001). "The curse of natural resources", European Economic Review, 45, 4-6, 827-838.

Schott, P. K. (2003). "One Size Fits All? Heckscher-Ohlin Specialization in Global Production", American Economic Review, 93, 3, 686-708.

Starosta de Waldemar, F. (2010). "How costly is rent-seeking to diversification: an empirical approach", CES Working Papers 2010.08, Paris: Centre d'Economie de la Sorbonne.

World Bank (2010). World Development Indicators 2010, The World Bank, Washington.

Xiang, C. (2007). "Diversification cones, trade costs and factor market linkages", Journal of International Economics, 71, 2, 448-466 
Table 1. Results of the regression analyses (Theil index - Non-monotonic specification)

\begin{tabular}{|c|c|c|c|c|c|c|c|c|}
\hline & $\begin{array}{l}\text { Pooled } \\
\text { OLS }\end{array}$ & $\begin{array}{l}\text { Pooled } \\
\text { OLS }\end{array}$ & Between-effects & Between-effects & Fixed-effects & $\begin{array}{l}\text { Fixed- } \\
\text { effects }\end{array}$ & GMM & GMM \\
\hline Centrality & $\begin{array}{l}-52.32 \\
(-21.84) * * *\end{array}$ & $\begin{array}{l}-46.16 \\
(-9.29) * * *\end{array}$ & $\begin{array}{l}-55.46 \\
(-24.18) * * *\end{array}$ & $\begin{array}{l}-52.72 \\
(-8.46) * * *\end{array}$ & $\begin{array}{l}-17.83 \\
(-4.42) * * *\end{array}$ & $\begin{array}{l}-17.75 \\
(-4.54) * * *\end{array}$ & $\begin{array}{l}-62.62 \\
(-9.43) * * *\end{array}$ & $\begin{array}{l}-53.89 \\
(-8.01)^{* * *}\end{array}$ \\
\hline GDP pc & & $\begin{array}{l}-5.31 \times 10^{-5} \\
(-1.45)\end{array}$ & & $\begin{array}{l}-3.79 \times 10^{-5} \\
(-0.74)\end{array}$ & & $\begin{array}{l}-1.38 \times 10^{-4} \\
(-3.04)^{* * *}\end{array}$ & & $\begin{array}{l}-3.59 \times 10^{-5} \\
(-0.84)\end{array}$ \\
\hline GDP pc squared & & $\begin{array}{l}1.23 \times 10^{-9} \\
(1.27)\end{array}$ & & $\begin{array}{l}1.26 \times 10^{-9} \\
(0.82)\end{array}$ & & $\begin{array}{l}2.30 \times 10^{-9} \\
(2.73) * * *\end{array}$ & & $\begin{array}{l}1.03 \times 10^{-9} \\
(0.96)\end{array}$ \\
\hline Period & 1980-2000 & 1980-2000 & 1980-2000 & $1980-2000$ & 1980-2000 & $1980-2000$ & $1980-2000$ & $1980-2000$ \\
\hline No. of countries & 91 & 91 & 91 & 91 & 91 & 91 & 91 & 91 \\
\hline No. of observations. & 1,864 & 1,864 & 1,864 & 1,864 & 1,864 & 1,864 & 1,864 & 1,864 \\
\hline $\mathrm{R}$-squared & 0.72 & 0.77 & 0.79 & 0.80 & 0.12 & 0.18 & & \\
\hline$A B$ Test for AR(2) p-value & & & & & & & 0.851 & 0.854 \\
\hline
\end{tabular}

Note: Country clustered robust $\mathrm{t}$-statistics in parentheses. $* * *$ statistically significant at $1 \%$. 
Table 2. Results of the regression analyses (Theil index - Monotonic specification)

\begin{tabular}{|c|c|c|c|c|}
\hline & $\begin{array}{l}\text { Pooled } \\
\text { OLS }\end{array}$ & Between-effects & Fixed-effects & GMM \\
\hline Centrality & $\begin{array}{l}-47.34 \\
(-14.09) * * *\end{array}$ & $\begin{array}{l}-51.95 \\
(-13.96) * * *\end{array}$ & $\begin{array}{l}-17.87 \\
(-4.98) * * *\end{array}$ & $\begin{array}{l}-56.54 \\
(-10.39)^{* * *}\end{array}$ \\
\hline Inverse GDP pc & $\begin{array}{l}351.39 \\
(2.39)^{* *}\end{array}$ & $\begin{array}{l}226.87 \\
(1.64)^{*}\end{array}$ & $\begin{array}{l}453.55 \\
(3.10)^{* * *}\end{array}$ & $\begin{array}{l}323.79 \\
(1.75)^{*}\end{array}$ \\
\hline Period & $1980-2000$ & $1980-2000$ & $1980-2000$ & $1980-2000$ \\
\hline No. of countries & 91 & 91 & 91 & 91 \\
\hline No. of obs. & 1,864 & 1,864 & 1,864 & 1,864 \\
\hline R-squared & 0.74 & 0.79 & 0.16 & \\
\hline $\mathrm{AB}$ Test for $\mathrm{AR}(2) \mathrm{p}$-value & & & & 0.911 \\
\hline
\end{tabular}

Note: Country clustered robust t-statistics in parentheses. ${ }^{* * *}, * *, *$ statistically significant at $1 \%, 5 \%$ and $10 \%$ respectively. 


\section{Appendix}

Table 3a. Robustness analysis I (Countries size included as independent variable - Non-monotonic specification)

\begin{tabular}{|c|c|c|c|c|c|c|c|c|}
\hline & $\begin{array}{l}\text { Pooled } \\
\text { OLS }\end{array}$ & $\begin{array}{l}\text { Between- } \\
\text { effects }\end{array}$ & $\begin{array}{l}\text { Fixed- } \\
\text { effects }\end{array}$ & GMM & $\begin{array}{l}\text { Pooled } \\
\text { OLS }\end{array}$ & $\begin{array}{l}\text { Between- } \\
\text { effects }\end{array}$ & $\begin{array}{l}\text { Fixed- } \\
\text { effects }\end{array}$ & GMM \\
\hline Centrality & $\begin{array}{l}-41.85 \\
(-7.96) * * *\end{array}$ & $\begin{array}{l}-49.22 \\
(-9.25) * * *\end{array}$ & $\begin{array}{l}-16.80 \\
(-4.55) * * *\end{array}$ & $\begin{array}{l}-48.38 \\
(-7.01) * * *\end{array}$ & $\begin{array}{l}-45.65 \\
(-9.18) * * *\end{array}$ & $\begin{array}{l}-53.16 \\
(-8.45) * * *\end{array}$ & $\begin{array}{l}-17.48 \\
(-4.50) * * *\end{array}$ & $\begin{array}{l}-54.19 \\
(-8.59) * * *\end{array}$ \\
\hline GDP pc & $\begin{array}{l}-8.11 \times 10^{-5} \\
(-2.19)^{* *}\end{array}$ & $\begin{array}{l}-6.67 \times 10^{-5} \\
(-1.53)\end{array}$ & $\begin{array}{l}-1.25 \times 10^{-4} \\
(-2.90) * * *\end{array}$ & $\begin{array}{l}-5.22 \times 10^{-5} \\
(-1.20)\end{array}$ & $\begin{array}{l}-5.73 \times 10^{-5} \\
(-1.59)\end{array}$ & $\begin{array}{l}-4.40 \times 10^{-5} \\
(-1.04)\end{array}$ & $\begin{array}{l}-1.39 \times 10^{-4} \\
(-2.98) * * *\end{array}$ & $\begin{array}{l}-2.68 \times 10^{-5} \\
(-0.67)\end{array}$ \\
\hline GDP pc squared & $\begin{array}{l}1.87 \times 10^{-9} \\
(1.98)^{* *}\end{array}$ & $\begin{array}{l}1.94 \times 10^{-9} \\
(1.50)\end{array}$ & $\begin{array}{l}2.09 \times 10^{-9} \\
(2.62)^{* * *} *\end{array}$ & $\begin{array}{l}1.27 \times 10^{-9} \\
(1.19)\end{array}$ & $\begin{array}{l}1.47 \times 10^{-9} \\
(1.56)\end{array}$ & $\begin{array}{l}1.58 \times 10^{-9} \\
(1.26)\end{array}$ & $\begin{array}{l}2.43 \times 10^{-9} \\
(2.65)^{* * *}\end{array}$ & $\begin{array}{l}8.70 \times 10^{-10} \\
(0.85)\end{array}$ \\
\hline Population & $\begin{array}{l}-1.63 \times 10^{-9} \\
(-6.40)^{* * *}\end{array}$ & $\begin{array}{l}-1.41 \times 10^{-9} \\
(-1.43)\end{array}$ & $\begin{array}{l}-3.57 \times 10^{-9} \\
(-2.33)^{* *}\end{array}$ & $\begin{array}{l}-1.44 \times 10^{-9} \\
(-5.11)^{* * *}\end{array}$ & & & & \\
\hline GDP & & & & & $\begin{array}{l}-9.08 \times 10^{-14} \\
(-1.54)\end{array}$ & $\begin{array}{l}-9.61 \times 10^{-14} \\
(-0.24)\end{array}$ & $\begin{array}{l}-1.08 \times 10^{-13} \\
(-1.52)\end{array}$ & $\begin{array}{l}-1.08 \times 10^{-13} \\
(-1.52)\end{array}$ \\
\hline Period & 1980-2000 & $1980-2000$ & $1980-2000$ & $1980-2000$ & $1980-2000$ & $1980-2000$ & $1980-2000$ & $1980-2000$ \\
\hline No. of countries & 91 & 91 & 91 & 91 & 91 & 91 & 91 & 91 \\
\hline No. of obs. & 1,864 & 1,864 & 1,864 & 1,864 & 1,864 & 1,864 & 1,864 & 1,864 \\
\hline R-squared & 0.76 & 0.82 & 0.20 & & 0.74 & 0.80 & 0.18 & \\
\hline $\mathrm{AB}$ Test for $\mathrm{AR}(2) \mathrm{p}$-value & & & & 0.873 & & & & 0.852 \\
\hline
\end{tabular}

Note: Country clustered robust t-statistics in parentheses. $* * *, * *$ statistically significant at $1 \%$ and $5 \%$ respectively. 
Table 3b. Robustness analysis I (Countries size included as independent variable - Monotonic specification)

\begin{tabular}{|c|c|c|c|c|c|c|c|c|}
\hline & $\begin{array}{l}\text { Pooled } \\
\text { OLS }\end{array}$ & $\begin{array}{l}\text { Between- } \\
\text { effects }\end{array}$ & $\begin{array}{l}\text { Fixed- } \\
\text { effects }\end{array}$ & GMM & $\begin{array}{l}\text { Pooled } \\
\text { OLS }\end{array}$ & $\begin{array}{l}\text { Between- } \\
\text { effects }\end{array}$ & $\begin{array}{l}\text { Fixed- } \\
\text { effects }\end{array}$ & GMM \\
\hline Centrality & $\begin{array}{l}-45.54 \\
(-13.46) * * *\end{array}$ & $\begin{array}{l}-49.98 \\
(-13.39) * * *\end{array}$ & $\begin{array}{l}-17.01 \\
(-4.90) * * *\end{array}$ & $\begin{array}{l}-52.63 \\
(-11.08) * * *\end{array}$ & $\begin{array}{l}-46.50 \\
(-13.74) * * *\end{array}$ & $\begin{array}{l}-51.35 \\
(-11.58) * * *\end{array}$ & $\begin{array}{l}-17.83 \\
(-4.97) * * *\end{array}$ & $\begin{array}{l}-54.56 \\
(-11.29) * * *\end{array}$ \\
\hline Population & $\begin{array}{l}-1.43 \times 10^{-9} \\
(-7.62) * * *\end{array}$ & $\begin{array}{l}-1.32 \times 10^{-9} \\
(-2.02)^{* *}\end{array}$ & $\begin{array}{l}-3.27 \times 10^{-9} \\
(-1.94)^{*}\end{array}$ & $\begin{array}{l}-1.35 \times 10^{-9} \\
(-6.52) * * *\end{array}$ & & & & \\
\hline GDP & & & & & $\begin{array}{l}-8.11 \times 10^{-14} \\
(-1.77)^{*}\end{array}$ & $\begin{array}{l}-5.12 \times 10^{-14} \\
(-0.15)\end{array}$ & $\begin{array}{l}-1.30 \times 10^{-13} \\
(-1.44)\end{array}$ & $\begin{array}{l}-1.75 \times 10^{-14} \\
(-0.36)\end{array}$ \\
\hline Period & $1980-2000$ & $1980-2000$ & $1980-2000$ & $1980-2000$ & $1980-2000$ & $1980-2000$ & $1980-2000$ & $1980-2000$ \\
\hline No. of countries & 91 & 91 & 91 & 91 & 91 & 91 & 91 & 91 \\
\hline No. of obs. & 1,864 & 1,864 & 1,864 & 1,864 & 1,864 & 1,864 & 1,864 & 1,864 \\
\hline R-squared & 0.76 & 0.82 & 0.17 & & 0.74 & 0.80 & 0.16 & \\
\hline $\mathrm{AB}$ Test for $\mathrm{AR}(2) \mathrm{p}$-value & & & & 0.919 & & & & 0.917 \\
\hline
\end{tabular}

Note: Country clustered robust t-statistics in parentheses. $* * *, * * *$ statistically significant at $1 \%, 5 \%$ and $10 \%$ respectively. 
Table 4a. Robustness analysis II (Herfindahl index - Non-monotonic specification)

\begin{tabular}{|c|c|c|c|c|c|c|c|c|}
\hline & OLS & OLS & OLS & OLS & $\mathrm{BE}$ & $\mathrm{BE}$ & $\mathrm{BE}$ & $\mathrm{BE}$ \\
\hline \multicolumn{9}{|l|}{ Panel A: Standard } \\
\hline Centrality & $\begin{array}{l}-6.43 \\
(-9.07) * * *\end{array}$ & $\begin{array}{l}-7.34 \\
(-6.14) * * *\end{array}$ & $\begin{array}{l}-7.14 \\
(-5.51) * * *\end{array}$ & $\begin{array}{l}-7.33 \\
(-6.09) * * *\end{array}$ & $\begin{array}{l}-6.74 \\
(-8.16) * * *\end{array}$ & $\begin{array}{l}-8.55 \\
(-5.45) * * *\end{array}$ & $\begin{array}{l}-8.44 \\
(-5.66) * * *\end{array}$ & $\begin{array}{l}-8.55 \\
(-5.93) * * *\end{array}$ \\
\hline GDP pc & & $\begin{array}{l}2.52 \times 10^{-6} \\
(0.37)\end{array}$ & $\begin{array}{l}1.22 \times 10^{-6} \\
(0.16)\end{array}$ & $\begin{array}{l}2.44 \times 10^{-6} \\
(0.35)\end{array}$ & & $\begin{array}{l}5.95 \times 10^{-6} \\
(0.72)\end{array}$ & $\begin{array}{l}5.22 \times 10^{-6} \\
(0.66)\end{array}$ & $\begin{array}{l}5.87 \times 10^{-6} \\
(0.65)\end{array}$ \\
\hline GDP pc squared & & $\begin{array}{l}3.08 \times 10^{-11} \\
(0.18)\end{array}$ & $\begin{array}{l}6.08 \times 10^{-11} \\
(0.33)\end{array}$ & $\begin{array}{l}3.54 \times 10^{-11} \\
(0.21)\end{array}$ & & $\begin{array}{l}1.15 \times 10^{-12} \\
(0.01)\end{array}$ & $\begin{array}{l}1.83 \times 10^{-11} \\
(0.09)\end{array}$ & $\begin{array}{l}5.59 \times 10^{-12} \\
(0.02)\end{array}$ \\
\hline Population & & & $\begin{array}{l}-7.56 \times 10^{-11} \\
(-1.52)\end{array}$ & & & & $\begin{array}{l}-3.57 \times 10^{-11} \\
(-0.26)\end{array}$ & \\
\hline GDP & & & & $\begin{array}{l}-1.76 \times 10^{-15} \\
(-0.28)\end{array}$ & & & & $\begin{array}{l}-1.35 \times 10^{-15} \\
(-0.10)\end{array}$ \\
\hline R-squared & 0.46 & 0.47 & 0.48 & 0.47 & 0.55 & 0.55 & 0.55 & 0.55 \\
\hline \multicolumn{9}{|l|}{ Panel B: Logistic } \\
\hline Centrality & $\begin{array}{l}-57.55 \\
(-15.01)^{* * *}\end{array}$ & $\begin{array}{l}-54.89 \\
(-7.75) * * *\end{array}$ & $\begin{array}{l}-51.35 \\
(-6.68) * * *\end{array}$ & $\begin{array}{l}-54.30 \\
(-7.70) * * *\end{array}$ & $\begin{array}{l}-60.90 \\
(-14.27) * * *\end{array}$ & $\begin{array}{l}-64.06 \\
(-7.66) * * *\end{array}$ & $\begin{array}{l}-60.73 \\
(-5.96) * * *\end{array}$ & $\begin{array}{l}-63.44 \\
(-6.42) * * *\end{array}$ \\
\hline GDP pc & & $\begin{array}{l}-3.73 \times 10^{-5} \\
(-0.77)\end{array}$ & $\begin{array}{l}-6.03 \times 10^{-5} \\
(-1.18)\end{array}$ & $\begin{array}{l}-4.23 \times 10^{-5} \\
(-0.89)\end{array}$ & & $\begin{array}{l}-1.60 \times 10^{-5} \\
(-0.24)\end{array}$ & $\begin{array}{l}-3.73 \times 10^{-5} \\
(-0.51)\end{array}$ & $\begin{array}{l}-2.27 \times 10^{-5} \\
(-0.37)\end{array}$ \\
\hline GDP pc squared & & $\begin{array}{l}1.10 \times 10^{-9} \\
(0.82)\end{array}$ & $\begin{array}{l}1.63 \times 10^{-9} \\
(1.20)\end{array}$ & $\begin{array}{l}1.38 \times 10^{-9} \\
(1.04)\end{array}$ & & $\begin{array}{l}1.03 \times 10^{-9} \\
(0.51)\end{array}$ & $\begin{array}{l}1.54 \times 10^{-9} \\
(0.70)\end{array}$ & $\begin{array}{l}1.38 \times 10^{-9} \\
(0.74)\end{array}$ \\
\hline Population & & & $\begin{array}{l}-1.34 \times 10^{-9} \\
(-4.17)^{* * *}\end{array}$ & & & & $\begin{array}{l}-1.08 \times 10^{-9} \\
(-1.58)\end{array}$ & \\
\hline GDP & & & & $\begin{array}{l}-1.07 \times 10^{-13} \\
(-1.17)\end{array}$ & & & & $\begin{array}{l}-1.06 \times 10^{-17} \\
(-0.28)\end{array}$ \\
\hline R-squared & 0.63 & 0.63 & 0.65 & 0.64 & 0.71 & 0.71 & 0.72 & 0.72 \\
\hline Period & $1980-2000$ & $1980-2000$ & $1980-2000$ & $1980-2000$ & $1980-2000$ & $1980-2000$ & 1980-2000 & 1980-2000 \\
\hline No. of countries & 91 & 91 & 91 & 91 & 91 & 91 & 91 & 91 \\
\hline No. of obs. & 1,864 & 1,864 & 1,864 & 1,864 & 1,864 & 1,864 & 1,864 & 1,864 \\
\hline
\end{tabular}

Note: Country clustered robust t-statistics in parentheses. $* * *, * * *$ statistically significant at $1 \%, 5 \%$ and $10 \%$ respectively. 
Table 4a. Robustness analysis II (cont.)

\begin{tabular}{|c|c|c|c|c|c|c|c|c|}
\hline & $\mathrm{FE}$ & FE & FE & $\mathrm{FE}$ & GMM & GMM & GMM & GMM \\
\hline \multicolumn{9}{|l|}{ Panel A: Standard } \\
\hline Centrality & $\begin{array}{l}-3.16 \\
(-3.47) * * *\end{array}$ & $\begin{array}{l}-3.08 \\
(-3.39) * * *\end{array}$ & $\begin{array}{l}-3.00 \\
(-3.34) * * *\end{array}$ & $\begin{array}{l}-3.04 \\
(-3.36) * * *\end{array}$ & $\begin{array}{l}-9.88 \\
(-5.47) * * *\end{array}$ & $\begin{array}{l}-8.68 \\
(-5.70) * * *\end{array}$ & $\begin{array}{l}-8.25 \\
(-5.51) * * *\end{array}$ & $\begin{array}{l}-8.42 \\
(-5.93) * * *\end{array}$ \\
\hline GDP pc & & $\begin{array}{l}-1.04 \times 10^{-5} \\
(-2.00)^{* *}\end{array}$ & $\begin{array}{l}-9.35 \times 10^{-6} \\
(-1.87)^{*}\end{array}$ & $\begin{array}{l}-1.06 \times 10^{-5} \\
(-1.97)^{*}\end{array}$ & & $\begin{array}{l}7.17 \times 10^{-6} \\
(0.87)\end{array}$ & $\begin{array}{l}6.24 \times 10^{-6} \\
(0.73)\end{array}$ & $\begin{array}{l}7.42 \times 10^{-6} \\
(0.97)\end{array}$ \\
\hline GDP pc squared & & $\begin{array}{l}2.07 \times 10^{-10} \\
(1.98)^{*}\end{array}$ & $\begin{array}{l}1.89 \times 10^{-10} \\
(1.88)^{*}\end{array}$ & $\begin{array}{l}2.25 \times 10^{-10} \\
(1.95)^{*}\end{array}$ & & $\begin{array}{l}-5.86 \times 10^{-11} \\
(0.01)\end{array}$ & $\begin{array}{l}-4.93 \times 10^{-11} \\
(-0.24)\end{array}$ & $\begin{array}{l}-7.43 \times 10^{-11} \\
(-0.41)\end{array}$ \\
\hline Population & & & $\begin{array}{l}-2.92 \times 10^{-10} \\
(-1.29)\end{array}$ & & & & $\begin{array}{l}-4.09 \times 10^{-11} \\
(-0.78)\end{array}$ & \\
\hline GDP & & & & $\begin{array}{l}-1.52 \times 10^{-14} \\
(-1.48)\end{array}$ & & & & $\begin{array}{l}8.07 \times 10^{-16} \\
(-0.12)\end{array}$ \\
\hline R-squared & 0.08 & 0.09 & 0.09 & 0.09 & & & & \\
\hline $\mathrm{AB}$ Test $\mathrm{AR}(2)$ & & & & & 0.855 & 0.788 & 0.754 & 0.768 \\
\hline \multicolumn{9}{|l|}{ Panel B: Logistic } \\
\hline Centrality & $\begin{array}{l}-21.84 \\
(-3.76)^{* * *}\end{array}$ & $\begin{array}{l}-21.39 \\
(-3.74)^{* * *}\end{array}$ & $\begin{array}{l}-20.21 \\
(-3.66) * * *\end{array}$ & $\begin{array}{l}-20.77 \\
(-3.68) * * *\end{array}$ & $\begin{array}{l}-75.91 \\
(-7.76) * * *\end{array}$ & $\begin{array}{l}-66.54 \\
(-7.31)^{* * *}\end{array}$ & $\begin{array}{l}-59.76 \\
(-6.37) * * *\end{array}$ & $\begin{array}{l}-65.18 \\
(-7.61) * * *\end{array}$ \\
\hline GDP pc & & $\begin{array}{l}-1.35 \times 10^{-4} \\
(-2.32)^{* *}\end{array}$ & $\begin{array}{l}-1.19 \times 10^{-4} \\
(-2.14)^{* *}\end{array}$ & $\begin{array}{l}-1.39 \times 10^{-4} \\
(-2.27)^{* *}\end{array}$ & & $\begin{array}{l}-4.59 \times 10^{-6} \\
(-0.08)\end{array}$ & $\begin{array}{l}-2.35 \times 10^{-5} \\
(-0.41)\end{array}$ & $\begin{array}{l}-1.41 \times 10^{-6} \\
(-0.03)\end{array}$ \\
\hline GDP pc squared & & $\begin{array}{l}2.43 \times 10^{-9} \\
(2.25)^{* *}\end{array}$ & $\begin{array}{l}2.17 \times 10^{-9} \\
(2.12)^{* *}\end{array}$ & $\begin{array}{l}2.74 \times 10^{-9} \\
(2.27)^{* *}\end{array}$ & & $\begin{array}{l}5.77 \times 10^{-10} \\
(0.39)\end{array}$ & $\begin{array}{l}8.49 \times 10^{-10} \\
(0.57)\end{array}$ & $\begin{array}{l}5.64 \times 10^{-10} \\
(0.39)\end{array}$ \\
\hline Population & & & $\begin{array}{l}-4.51 \times 10^{-9} \\
(-2.18)^{* * *}\end{array}$ & & & & $\begin{array}{l}-1.09 \times 10^{-9} \\
(-3.09)^{* * *}\end{array}$ & \\
\hline GDP & & & & $\begin{array}{l}-2.58 \times 10^{-13} \\
(-2.03)^{* *}\end{array}$ & & & & $\begin{array}{l}-8.10 \times 10^{-14} \\
(-0.84)\end{array}$ \\
\hline R-squared & 0.09 & 0.11 & 0.13 & 0.12 & & & & \\
\hline AB Test AR(2) & & & & & 0.989 & 0.961 & 0.898 & 0.951 \\
\hline Period & $1980-2000$ & $1980-2000$ & $1980-2000$ & $1980-2000$ & $1980-2000$ & $1980-2000$ & $1980-2000$ & 1980-2000 \\
\hline No. of countries & 91 & 91 & 91 & 91 & 91 & 91 & 91 & 91 \\
\hline No. of obs. & 1,864 & 1,864 & 1,864 & 1,864 & 1,864 & 1,864 & 1,864 & 1,864 \\
\hline
\end{tabular}

Note: Country clustered robust t-statistics in parentheses. ***, **, * statistically significant at $1 \%, 5 \%$ and $10 \%$ respectively. 
Table 4b. Robustness analysis II (Herfindahl index - Monotonic specification)

\begin{tabular}{|c|c|c|c|c|c|c|c|c|c|c|c|c|}
\hline & OLS & OLS & OLS & $\mathrm{BE}$ & $\mathrm{BE}$ & $\mathrm{BE}$ & $\mathrm{FE}$ & FE & FE & GMM & GMM & GMM \\
\hline \multicolumn{13}{|l|}{ Panel A: Standard } \\
\hline Centrality & $\begin{array}{l}-6.01 \\
(-6.02) * * *\end{array}$ & $\begin{array}{l}-5.86 \\
(-5.70)^{* * *}\end{array}$ & $\begin{array}{l}-6.10 \\
(-5.96) * * *\end{array}$ & $\begin{array}{l}-6.58 \\
(-5.88) * * *\end{array}$ & $\begin{array}{l}-6.43 \\
(-5.10) * * *\end{array}$ & $\begin{array}{l}-6.73 \\
(-5.30) * * *\end{array}$ & $\begin{array}{l}-3.16 \\
(-3.78) * * *\end{array}$ & $\begin{array}{l}-3.12 \\
(-3.75) * * *\end{array}$ & $\begin{array}{l}-3.16 \\
(-3.78) * * *\end{array}$ & $\begin{array}{l}-8.82 \\
(-5.97) * * *\end{array}$ & $\begin{array}{l}-7.55 \\
(-5.54)^{* * *}\end{array}$ & $\begin{array}{l}-7.92 \\
(-5.95) * * *\end{array}$ \\
\hline Inverse GDP pc & $\begin{array}{l}29.55 \\
(0.91)\end{array}$ & $\begin{array}{l}34.52 \\
(0.91)\end{array}$ & $\begin{array}{l}29.97 \\
(0.82)\end{array}$ & $\begin{array}{l}10.14 \\
(0.31)\end{array}$ & $\begin{array}{l}15.37 \\
(0.39)\end{array}$ & $\begin{array}{l}10.29 \\
(0.24)\end{array}$ & $\begin{array}{l}60.93 \\
(2.00) * *\end{array}$ & $\begin{array}{l}55.53 \\
(1.72)^{*}\end{array}$ & $\begin{array}{l}60.38 \\
(1.97)^{*}\end{array}$ & $\begin{array}{l}32.33 \\
(0.72) * *\end{array}$ & $\begin{array}{l}22.76 \\
(0.53)\end{array}$ & $\begin{array}{l}32.32 \\
(0.76)\end{array}$ \\
\hline Population & & $\begin{array}{l}-1.17 \times 10^{-10} \\
(-3.21)^{* * *}\end{array}$ & & & $\begin{array}{l}-1.02 \times 10^{-10} \\
(-0.60)\end{array}$ & & & $\begin{array}{l}-1.63 \times 10^{-10} \\
(-0.67)\end{array}$ & & & $\begin{array}{l}-1.15 \times 10^{-10} \\
(-2.84)^{* * *}\end{array}$ & \\
\hline GDP & & & $\begin{array}{l}8.74 \times 10^{-15} \\
(1.49)\end{array}$ & & & $\begin{array}{l}1.26 \times 10^{-14} \\
(0.58)\end{array}$ & & & $\begin{array}{l}-5.37 \times 10^{-15} \\
(-0.75)\end{array}$ & & & $\begin{array}{l}2.33 \times 10^{-14} \\
(2.15)^{* *}\end{array}$ \\
\hline $\begin{array}{l}\text { R-squared } \\
\text { AB Test AR(2) }\end{array}$ & 0.47 & 0.47 & 0.47 & 0.52 & 0.53 & 0.53 & 0.10 & 0.10 & 0.10 & 0.753 & 0.664 & 0.686 \\
\hline \multicolumn{13}{|l|}{ Panel B: Logistic } \\
\hline Centrality & $\begin{array}{l}-53.45 \\
(-10.11)^{* * *}\end{array}$ & $\begin{array}{l}-51.87 \\
(-9.52)^{* * *}\end{array}$ & $\begin{array}{l}-52.74 \\
(-9.78) * * *\end{array}$ & $\begin{array}{l}-58.84 \\
(-9.10)^{* * *}\end{array}$ & $\begin{array}{l}-57.19 \\
(-8.55)^{* * *}\end{array}$ & $\begin{array}{l}-58.08 \\
(-9.34)^{* * *}\end{array}$ & $\begin{array}{l}-21.89 \\
(-4.21)^{* * *}\end{array}$ & $\begin{array}{l}-20.86 \\
(-4.07)^{* * *}\end{array}$ & $\begin{array}{l}-21.83 \\
(-4.20)^{* * *}\end{array}$ & $\begin{array}{l}-67.12 \\
(-8.37)^{* * *}\end{array}$ & $\begin{array}{l}-61.26 \\
(-8.47)^{* * *}\end{array}$ & $\begin{array}{l}-62.25 \\
(-8.71)^{* * *}\end{array}$ \\
\hline Inverse GDP pc & $\begin{array}{l}289.80 \\
(1.43)\end{array}$ & $\begin{array}{l}343.28 \\
(1.64)\end{array}$ & $\begin{array}{l}286.51 \\
(1.41)\end{array}$ & $\begin{array}{l}133.17 \\
(0.49)\end{array}$ & $\begin{array}{l}190.19 \\
(0.70)\end{array}$ & $\begin{array}{l}131.80 \\
(0.66)\end{array}$ & $\begin{array}{l}531.19 \\
(2.51)^{* *}\end{array}$ & $\begin{array}{l}401.04 \\
(2.03)^{* *}\end{array}$ & $\begin{array}{l}510.92 \\
(2.45) * *\end{array}$ & $\begin{array}{l}303.67 \\
(1.17)\end{array}$ & $\begin{array}{l}258.00 \\
(1.06)\end{array}$ & $\begin{array}{l}314.94 \\
(1.26)\end{array}$ \\
\hline Population & & $\begin{array}{l}-1.26 \times 10^{-9} \\
(-5.41)^{* * * *}\end{array}$ & & & $\begin{array}{l}-1.11 \times 10^{-9} \\
(-1.45)\end{array}$ & & & $\begin{array}{l}-3.92 \times 10^{-9} \\
(-1.79)^{*}\end{array}$ & & & $\begin{array}{l}-1.19 \times 10^{-9} \\
(-4.78)^{* * *}\end{array}$ & \\
\hline GDP & & & $\begin{array}{l}-6.83 \times 10^{-14} \\
(-1.02)\end{array}$ & & & $\begin{array}{l}-3.06 \times 10^{-14} \\
(-0.09)\end{array}$ & & & $\begin{array}{l}-1.99 \times 10^{-13} \\
(-1.39)\end{array}$ & & & $\begin{array}{l}-1.26 \times 10^{-14} \\
(0.16)\end{array}$ \\
\hline R-squared & 0.64 & 0.65 & 0.64 & 0.71 & 0.72 & 0.71 & 0.11 & 0.12 & 0.12 & & & \\
\hline AB Test AR(2) & & & & & & & & & & 0.913 & 0.869 & 0.871 \\
\hline Period & $1980-2000$ & $1980-2000$ & $1980-2000$ & $1980-2000$ & $1980-2000$ & $1980-2000$ & $1980-2000$ & $1980-2000$ & $1980-2000$ & $1980-2000$ & $1980-2000$ & $1980-2000$ \\
\hline No. of countries & 91 & 91 & 91 & 91 & 91 & 91 & 91 & 91 & 91 & 91 & 91 & 91 \\
\hline No. of obs. & 1,864 & 1,864 & 1,864 & 1,864 & 1,864 & 1,864 & 1,864 & 1,864 & 1,864 & 1,864 & 1,864 & 1,864 \\
\hline
\end{tabular}

Note: Country clustered robust t-statistics in parentheses. $* * *, * * *$ statistically significant at $1 \%, 5 \%$ and $10 \%$ respectively. 
Table 5a. Robustness analysis II (Gini coefficient - Non-monotonic specification)

\begin{tabular}{|c|c|c|c|c|c|c|c|c|}
\hline & OLS & OLS & OLS & OLS & $\mathrm{BE}$ & $\mathrm{BE}$ & $\mathrm{BE}$ & $\mathrm{BE}$ \\
\hline \multicolumn{9}{|l|}{ Panel A: Standard } \\
\hline Centrality & $\begin{array}{l}-2.49 \\
(-13.12) * * *\end{array}$ & $\begin{array}{l}-1.52 \\
(-5.76) * * *\end{array}$ & $\begin{array}{l}-1.20 \\
(-4.82) * * *\end{array}$ & $\begin{array}{l}-1.45 \\
(-5.82) * * *\end{array}$ & $\begin{array}{l}-2.70 \\
(-6.80) * * *\end{array}$ & $\begin{array}{l}-1.85 \\
(-6.80) * * *\end{array}$ & $\begin{array}{l}-1.50 \\
(-4.31) * * *\end{array}$ & $\begin{array}{l}-1.78 \\
(-6.56) * * *\end{array}$ \\
\hline GDP pc & & $\begin{array}{l}-4.73 \times 10^{-6} \\
(-2.17)^{* *}\end{array}$ & $\begin{array}{l}-6.77 \times 10^{-6} \\
(-3.38)^{* * *} *\end{array}$ & $\begin{array}{l}-5.27 \times 10^{-6} \\
(-2.67) * * *\end{array}$ & & $\begin{array}{l}-3.90 \times 10^{-6} \\
(-1.68)^{*}\end{array}$ & $\begin{array}{l}-6.12 \times 10^{-6} \\
(-2.32)^{* *}\end{array}$ & $\begin{array}{l}-4.67 \times 10^{-6} \\
(-1.76)^{*}\end{array}$ \\
\hline GDP pc squared & & $\begin{array}{l}4.91 \times 10^{-11} \\
(0.71)\end{array}$ & $\begin{array}{l}9.65 \times 10^{-11} \\
(1.57)\end{array}$ & $\begin{array}{l}8.02 \times 10^{-11} \\
(1.32)\end{array}$ & & $\begin{array}{l}4.37 \times 10^{-11} \\
(0.50)\end{array}$ & $\begin{array}{l}9.60 \times 10^{-11} \\
(1.08)\end{array}$ & $\begin{array}{l}8.35 \times 10^{-11} \\
(0.83)\end{array}$ \\
\hline Population & & & $\begin{array}{l}-1.19 \times 10^{-10} \\
(-8.51)^{* * *}\end{array}$ & & & & $\begin{array}{l}-1.09 \times 10^{-10} \\
(-1.05)\end{array}$ & \\
\hline GDP & & & & $\begin{array}{l}-1.18 \times 10^{-14} \\
(-2.11)^{* *}\end{array}$ & & & & $\begin{array}{l}-1.21 \times 10^{-14} \\
(-0.28)\end{array}$ \\
\hline R-squared & 0.62 & 0.70 & 0.75 & 0.71 & 0.71 & 0.75 & 0.79 & 0.77 \\
\hline \multicolumn{9}{|l|}{ Panel B: Logistic } \\
\hline Centrality & $\begin{array}{l}-54.69 \\
(-24.82) * * *\end{array}$ & $\begin{array}{l}-46.20 \\
(-10.19) * * *\end{array}$ & $\begin{array}{l}-41.39 \\
(-9.15) * * *\end{array}$ & $\begin{array}{l}-45.74 \\
(-10.24) * * *\end{array}$ & $\begin{array}{l}-57.78 \\
(-23.06) * * *\end{array}$ & $\begin{array}{l}-52.92 \\
(-10.75) * * *\end{array}$ & $\begin{array}{l}-47.68 \\
(-8.98) * * *\end{array}$ & $\begin{array}{l}-52.38 \\
(-8.49) * * *\end{array}$ \\
\hline GDP pc & & $\begin{array}{l}-6.79 \times 10^{-5} \\
(-2.10)^{* *}\end{array}$ & $\begin{array}{l}-9.91 \times 10^{-5} \\
(-3.13)^{* * *} *\end{array}$ & $\begin{array}{l}-7.18 \times 10^{-5} \\
(-2.24)^{* *}\end{array}$ & & $\begin{array}{l}-5.82 \times 10^{-5} \\
(-1.81)^{*}\end{array}$ & $\begin{array}{l}-9.18 \times 10^{-5} \\
(-2.56)^{* * *}\end{array}$ & $\begin{array}{l}-6.41 \times 10^{-5} \\
(-1.73)^{*}\end{array}$ \\
\hline GDP pc squared & & $\begin{array}{l}1.48 \times 10^{-9} \\
(1.82)^{*}\end{array}$ & $\begin{array}{l}2.21 \times 10^{-9} \\
(2.82)^{* * *} *\end{array}$ & $\begin{array}{l}1.70 \times 10^{--9} \\
(2.12)^{* *}\end{array}$ & & $\begin{array}{l}1.66 \times 10^{-9} \\
(1.95)^{*}\end{array}$ & $\begin{array}{l}2.44 \times 10^{-9} \\
(2.50)^{* *}\end{array}$ & $\begin{array}{l}1.96 \times 10^{-9} \\
(1.94)^{* *}\end{array}$ \\
\hline Population & & & $\begin{array}{l}-1.82 \times 10^{-9} \\
(-6.82)^{* * *}\end{array}$ & & & & $\begin{array}{l}-1.65 \times 10^{-9} \\
(-2.32)^{* *}\end{array}$ & \\
\hline GDP & & & & $\begin{array}{l}-8.37 \times 10^{-14} \\
(-1.45)\end{array}$ & & & & $\begin{array}{l}-9.30 \times 10^{-14} \\
(-0.16)\end{array}$ \\
\hline R-squared & 0.77 & 0.78 & 0.81 & 0.78 & 0.83 & 0.83 & 0.86 & 0.84 \\
\hline Period & $1980-2000$ & $1980-2000$ & $1980-2000$ & $1980-2000$ & $1980-2000$ & 1980-2000 & $1980-2000$ & $1980-2000$ \\
\hline No. of countries & 91 & 91 & 91 & 91 & 91 & 91 & 91 & 91 \\
\hline No. of obs. & 1,864 & 1,864 & 1,864 & 1,864 & 1,864 & 1,864 & 1,864 & 1,864 \\
\hline
\end{tabular}

Note: Country clustered robust t-statistics in parentheses. $* * *, * * *$ statistically significant at $1 \%, 5 \%$ and $10 \%$ respectively. 
Table 5a. Robustness analysis II (cont.)

\begin{tabular}{|c|c|c|c|c|c|c|c|c|}
\hline & FE & FE & FE & FE & GMM & GMM & GMM & GMM \\
\hline \multicolumn{9}{|l|}{ Panel A: Standard } \\
\hline Centrality & $\begin{array}{l}-0.24 \\
(-1.46)\end{array}$ & $\begin{array}{l}-0.28 \\
(-2.06) * *\end{array}$ & $\begin{array}{l}-0.20 \\
(-1.64)\end{array}$ & $\begin{array}{l}-0.26 \\
(-1.95)^{*}\end{array}$ & $\begin{array}{l}-2.39 \\
(-7.35) * * *\end{array}$ & $\begin{array}{l}-1.99 \\
(-5.72) * * *\end{array}$ & $\begin{array}{l}-1.60 \\
(-4.44) * * *\end{array}$ & $\begin{array}{l}-2.06 \\
(-5.99) * * *\end{array}$ \\
\hline GDP pc & & $\begin{array}{l}-1.06 \times 10^{-5} \\
(-3.69)^{* * *}\end{array}$ & $\begin{array}{l}-9.46 \times 10^{-6} \\
(-3.51)^{* * *}\end{array}$ & $\begin{array}{l}-1.07 \times 10^{-5} \\
(-3.67)^{* * *}\end{array}$ & & $\begin{array}{l}-3.88 \times 10^{-6} \\
(-1.58)\end{array}$ & $\begin{array}{l}-5.01 \times 10^{-6} \\
(-2.08)^{* *}\end{array}$ & $\begin{array}{l}-3.36 \times 10^{-6} \\
(-1.49)\end{array}$ \\
\hline GDP pc squared & & $\begin{array}{l}1.54 \times 10^{-10} \\
(3.17)^{* * *}\end{array}$ & $\begin{array}{l}1.36 \times 10^{-10} \\
(3.02)^{* * *}\end{array}$ & $\begin{array}{l}1.63 \times 10^{-10} \\
(3.13)^{* * *}\end{array}$ & & $\begin{array}{l}4.44 \times 10^{-11} \\
(0.60)\end{array}$ & $\begin{array}{l}6.03 \times 10^{-11} \\
(0.86)\end{array}$ & $\begin{array}{l}4.58 \times 10^{-11} \\
(0.68)\end{array}$ \\
\hline Population & & & $\begin{array}{l}-3.03 \times 10^{-10} \\
(-4.65)^{* * *}\end{array}$ & & & & $\begin{array}{l}-1.06 \times 10^{-10} \\
(-6.76)^{* * *}\end{array}$ & \\
\hline GDP & & & & $\begin{array}{l}-7.86 \times 10^{-15} \\
(-1.26)\end{array}$ & & & & $\begin{array}{l}-1.03 \times 10^{-14} \\
(-1.85)^{*}\end{array}$ \\
\hline $\begin{array}{l}\text { R-squared } \\
\text { AB Test AR(2) }\end{array}$ & 0.01 & 0.17 & 0.23 & 0.17 & 0.679 & 0.721 & 0.708 & 0.711 \\
\hline \multicolumn{9}{|l|}{ Panel B: Logistic } \\
\hline Centrality & $\begin{array}{l}-21.20 \\
(-5.54) * * *\end{array}$ & $\begin{array}{l}-21.45 \\
(-5.66)^{* * *}\end{array}$ & $\begin{array}{l}-20.53 \\
(-5.69) * * *\end{array}$ & $\begin{array}{l}-21.31 \\
(-5.66) * * *\end{array}$ & $\begin{array}{l}-61.98 \\
(-10.40) * * *\end{array}$ & $\begin{array}{l}-51.61 \\
(-8.86)^{* * * *}\end{array}$ & $\begin{array}{l}-47.08 \\
(-7.94) * * * *\end{array}$ & $\begin{array}{l}-52.79 \\
(-9.39) * * *\end{array}$ \\
\hline GDP pc & & $\begin{array}{l}-1.34 \times 10^{-4} \\
(-3.30)^{* * *}\end{array}$ & $\begin{array}{l}-1.21 \times 10^{-4} \\
(-3.14)^{* * *}\end{array}$ & $\begin{array}{l}-1.35 \times 10^{-4} \\
(-3.23)^{* * *}\end{array}$ & & $\begin{array}{l}-5.69 \times 10^{-5} \\
(-1.53)\end{array}$ & $\begin{array}{l}-7.22 \times 10^{-5} \\
(-1.95)^{*}\end{array}$ & $\begin{array}{l}-4.72 \times 10^{-5} \\
(-1.34)\end{array}$ \\
\hline GDP pc squared & & $\begin{array}{l}2.09 \times 10^{-9} \\
(2.65)^{* * *}\end{array}$ & $\begin{array}{l}1.89 \times 10^{-9} \\
(2.52)^{* *}\end{array}$ & $\begin{array}{l}2.16 \times 10^{-9} \\
(2.51)^{* *}\end{array}$ & & $\begin{array}{l}1.38 \times 10^{-9} \\
(1.52)\end{array}$ & $\begin{array}{l}1.62 \times 10^{-9} \\
(1.84)^{*}\end{array}$ & $\begin{array}{l}1.23 \times 10^{-9} \\
(1.43)\end{array}$ \\
\hline Population & & & $\begin{array}{l}-3.49 \times 10^{-9} \\
(-2.36)^{* *}\end{array}$ & & & & $\begin{array}{l}-1.65 \times 10^{-9} \\
(-5.82)^{* * *}\end{array}$ & \\
\hline GDP & & & & $\begin{array}{l}-5.71 \times 10^{-14} \\
(-0.77)\end{array}$ & & & & $\begin{array}{l}-6.62 \times 10^{-14} \\
(-1.15)\end{array}$ \\
\hline R-squared & 0.19 & 0.25 & 0.13 & 0.12 & & & & \\
\hline AB Test AR(2) & & & & & 0.817 & 0.783 & 0.788 & 0.794 \\
\hline Period & $1980-2000$ & $1980-2000$ & $1980-2000$ & $1980-2000$ & $1980-2000$ & $1980-2000$ & $1980-2000$ & $1980-2000$ \\
\hline No. of countries & 91 & 91 & 91 & 91 & 91 & 91 & 91 & 91 \\
\hline No. of obs. & 1,864 & 1,864 & 1,864 & 1,864 & 1,864 & 1,864 & 1,864 & 1,864 \\
\hline
\end{tabular}

Note: Country clustered robust t-statistics in parentheses. $* * *, * *, *$ statistically significant at $1 \%, 5 \%$ and $10 \%$ respectively. 
Table 5b. Robustness analysis II (Gini coefficient - Monotonic specification)

\begin{tabular}{|c|c|c|c|c|c|c|c|c|c|c|c|c|}
\hline & OLS & OLS & OLS & $\mathrm{BE}$ & $\mathrm{BE}$ & $\mathrm{BE}$ & $\mathrm{FE}$ & $\mathrm{FE}$ & $\mathrm{FE}$ & GMM & GMM & GMM \\
\hline \multicolumn{13}{|l|}{ Panel A: Standard } \\
\hline Centrality & $\begin{array}{l}-2.25 \\
(-11.25)^{* * *}\end{array}$ & $\begin{array}{l}-2.15 \\
(-11.11) * * *\end{array}$ & $\begin{array}{l}-2.08 \\
(-10.85)^{* * *}\end{array}$ & $\begin{array}{l}-2.54 \\
(-10.62) * * *\end{array}$ & $\begin{array}{l}-2.43 \\
(-10.36)^{* * *}\end{array}$ & $\begin{array}{l}-2.36 \\
(-7.65) * * *\end{array}$ & $\begin{array}{l}-0.24 \\
(-1.53)\end{array}$ & $\begin{array}{l}-0.15 \\
(-1.03)\end{array}$ & $\begin{array}{l}-0.23 \\
(-1.53)\end{array}$ & $\begin{array}{l}-2.12 \\
(-8.12)^{* * *}\end{array}$ & $\begin{array}{l}-2.14 \\
(-9.90) * * *\end{array}$ & $\begin{array}{l}-2.31 \\
(-7.71)^{* * *}\end{array}$ \\
\hline Inverse GDP pc & $\begin{array}{l}16.73 \\
(2.68)^{* * *}\end{array}$ & $\begin{array}{l}20.26 \\
(3.38)^{* * *}\end{array}$ & $\begin{array}{l}18.87 \\
(3.35)^{* * *}\end{array}$ & $\begin{array}{l}10.07 \\
(1.08)\end{array}$ & $\begin{array}{l}13.94 \\
(2.11)^{* *}\end{array}$ & $\begin{array}{l}9.89 \\
(1.51)\end{array}$ & $\begin{array}{l}20.30 \\
(2.10) * *\end{array}$ & $\begin{array}{l}8.87 \\
(2.13) * *\end{array}$ & $\begin{array}{l}18.63 \\
(2.11)^{* *}\end{array}$ & $\begin{array}{l}14.94 \\
(2.22)^{* *}\end{array}$ & $\begin{array}{l}16.53 \\
(2.58) * * *\end{array}$ & $\begin{array}{l}15.83 \\
(2.14)^{* *}\end{array}$ \\
\hline Population & & $\begin{array}{l}-8.31 \times 10^{-11} \\
(-5.21)^{* * *}\end{array}$ & & & $\begin{array}{l}-7.52 \times 10^{-11} \\
(-1.36)\end{array}$ & & & $\begin{array}{l}-3.44 \times 10^{-10} \\
(-4.44)^{* * *}\end{array}$ & & & $\begin{array}{l}-7.32 \times 10^{-11} \\
(-5.43)^{* * *}\end{array}$ & \\
\hline GDP & & & $\begin{array}{l}-1.68 \times 10^{-14} \\
(-3.35)^{* * *}\end{array}$ & & & $\begin{array}{l}-1.51 \times 10^{-14} \\
(-0.26)\end{array}$ & & & $\begin{array}{l}-1.54 \times 10^{-14} \\
(-1.87)^{*}\end{array}$ & & & $\begin{array}{l}-1.47 \times 10^{-14} \\
(3.28) * * *\end{array}$ \\
\hline R-squared & 0.63 & 0.65 & 0.66 & 0.71 & 0.73 & 0.74 & 0.03 & 0.10 & 0.05 & & & \\
\hline $\mathrm{AB}$ Test AR(2) & & & & & & & & & & 0.700 & 0.717 & 0.730 \\
\hline \multicolumn{13}{|l|}{ Panel B: Logistic } \\
\hline Centrality & $\begin{array}{l}-48.37 \\
(-16.26)^{* * *}\end{array}$ & $\begin{array}{l}-46.41 \\
(-15.85) * * *\end{array}$ & $\begin{array}{l}-47.48 \\
(-16.00) * * *\end{array}$ & $\begin{array}{l}-52.53 \\
(-12.48)^{* * *}\end{array}$ & $\begin{array}{l}-50.33 \\
(-12.38) * * *\end{array}$ & $\begin{array}{l}-51.84 \\
(-12.99) * * *\end{array}$ & $\begin{array}{l}-21.25 \\
(-6.13)^{* * *}\end{array}$ & $\begin{array}{l}-20.39 \\
(-6.04)^{* * *}\end{array}$ & $\begin{array}{l}-21.21 \\
(-6.13) * * *\end{array}$ & $\begin{array}{l}-55.99 \\
(-12.44) * * *\end{array}$ & $\begin{array}{l}-52.50 \\
(-13.48) * * *\end{array}$ & $\begin{array}{l}-55.10 \\
(-13.41) * * *\end{array}$ \\
\hline Inverse GDP pc & $\begin{array}{l}446.23 \\
(3.31)^{* * *}\end{array}$ & $\begin{array}{l}512.56 \\
(3.73)^{* * *}\end{array}$ & $\begin{array}{l}442.11 \\
(3.29) * * *\end{array}$ & $\begin{array}{l}415.03 \\
(2.50)^{* *}\end{array}$ & $\begin{array}{l}415.44 \\
(2.35)^{* * *}\end{array}$ & $\begin{array}{l}338.97 \\
(2.89) * * *\end{array}$ & $\begin{array}{l}446.05 \\
(3.26)^{* * * *}\end{array}$ & $\begin{array}{l}337.91 \\
(3.16)^{* * * *}\end{array}$ & $\begin{array}{l}433.38 \\
(3.22) * * *\end{array}$ & $\begin{array}{l}386.91 \\
(2.37) * *\end{array}$ & $\begin{array}{l}400.90 \\
(2.66)^{* * *}\end{array}$ & $\begin{array}{l}407.09 \\
(2.52)^{* *}\end{array}$ \\
\hline Population & & $\begin{array}{l}-1.56 \times 10^{-9} \\
(-7.45)^{* * * *}\end{array}$ & & & $\begin{array}{l}-1.47 \times 10^{-9} \\
(-1.64)\end{array}$ & & & $\begin{array}{l}-3.26 \times 10^{-9} \\
(-1.95)^{*}\end{array}$ & & & $\begin{array}{l}-1.48 \times 10^{-9} \\
(-6.54)^{* * * *}\end{array}$ & \\
\hline GDP & & & $\begin{array}{l}-8.54 \times 10^{-14} \\
(-1.80)^{*}\end{array}$ & & & $\begin{array}{l}-5.85 \times 10^{-14} \\
(-0.13)\end{array}$ & & & $\begin{array}{l}-1.25 \times 10^{-13} \\
(-1.47)\end{array}$ & & & $\begin{array}{l}-2.66 \times 10^{-14} \\
(-0.56)\end{array}$ \\
\hline R-squared & 0.79 & 0.81 & 0.79 & 0.84 & 0.86 & 0.84 & 0.22 & 0.24 & 0.23 & & & \\
\hline AB Test AR(2) & & & & & & & & & & 0.879 & 0.880 & 0.883 \\
\hline Period & $1980-2000$ & $1980-2000$ & $1980-2000$ & $1980-2000$ & $1980-2000$ & $1980-2000$ & $1980-2000$ & $1980-2000$ & $1980-2000$ & $1980-2000$ & 1980-2000 & $1980-2000$ \\
\hline No. of countries & 91 & 91 & 91 & 91 & 91 & 91 & 91 & 91 & 91 & 91 & 91 & 91 \\
\hline No. of obs. & 1,864 & 1,864 & 1,864 & 1,864 & 1,864 & 1,864 & 1,864 & 1,864 & 1,864 & 1,864 & 1,864 & 1,864 \\
\hline
\end{tabular}

Note: Country clustered robust t-statistics in parentheses. $* * *, * * *$ statistically significant at $1 \%, 5 \%$ and $10 \%$ respectively. 
Figure 1. Diversification and GDP per capita

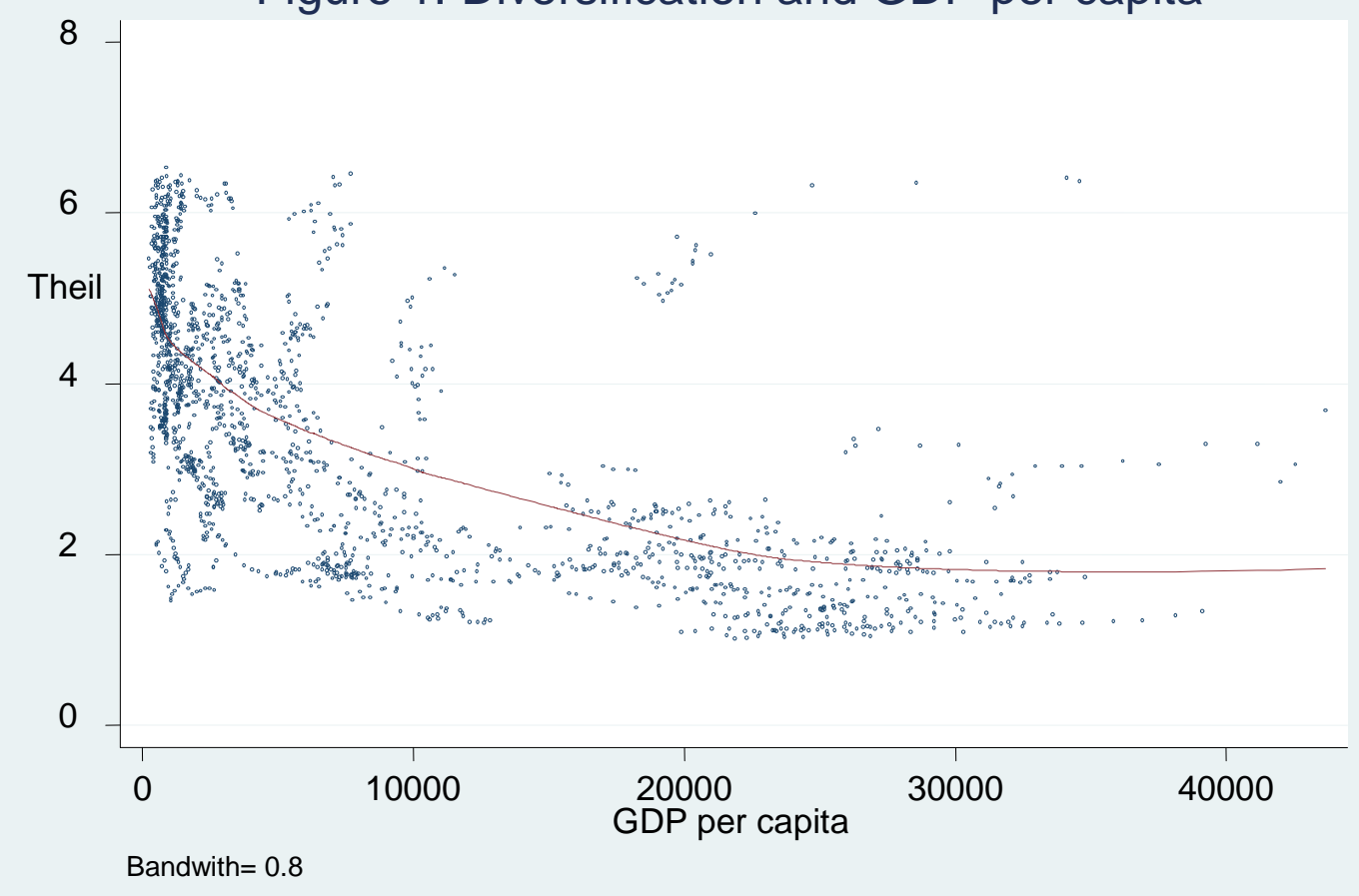




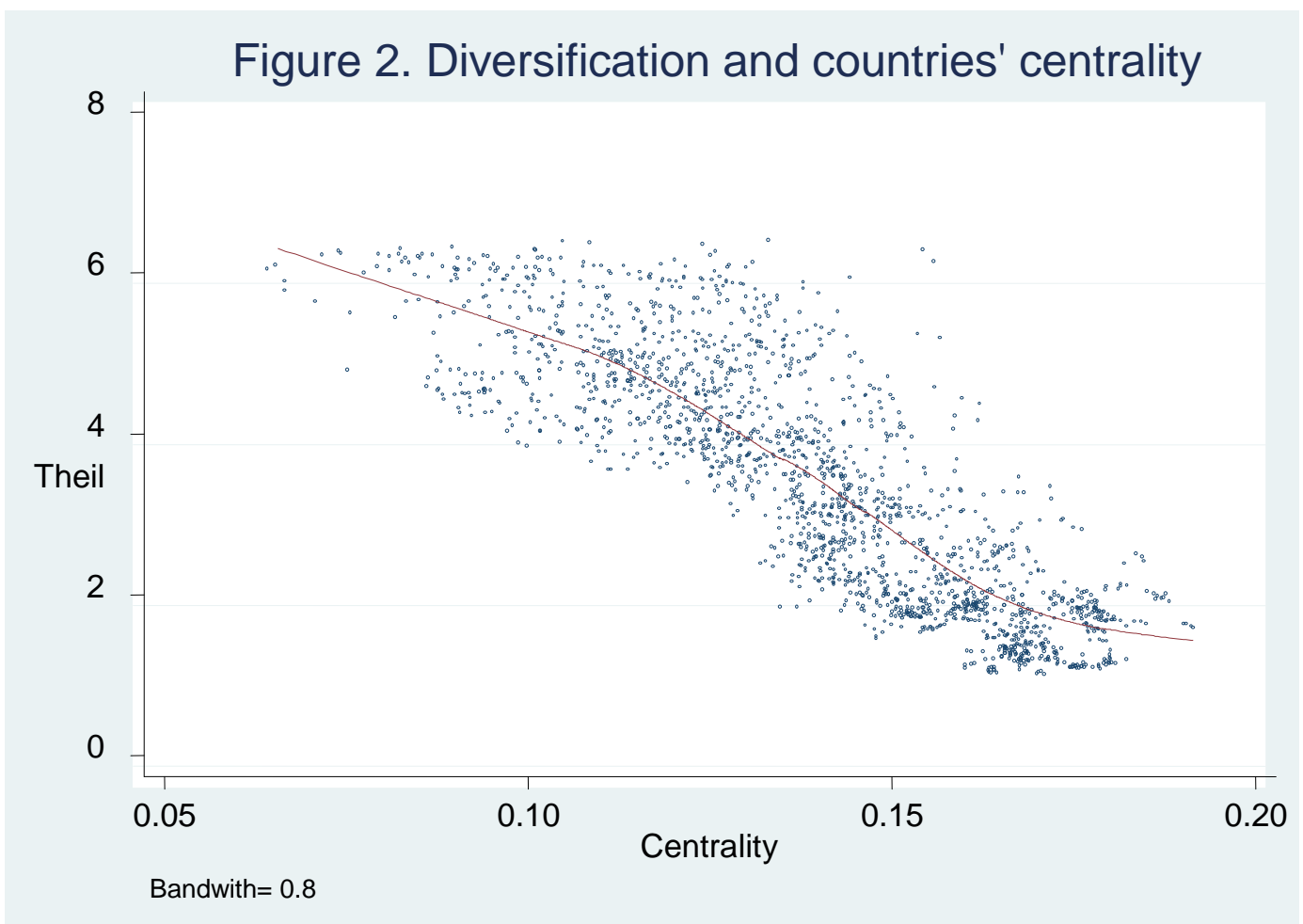




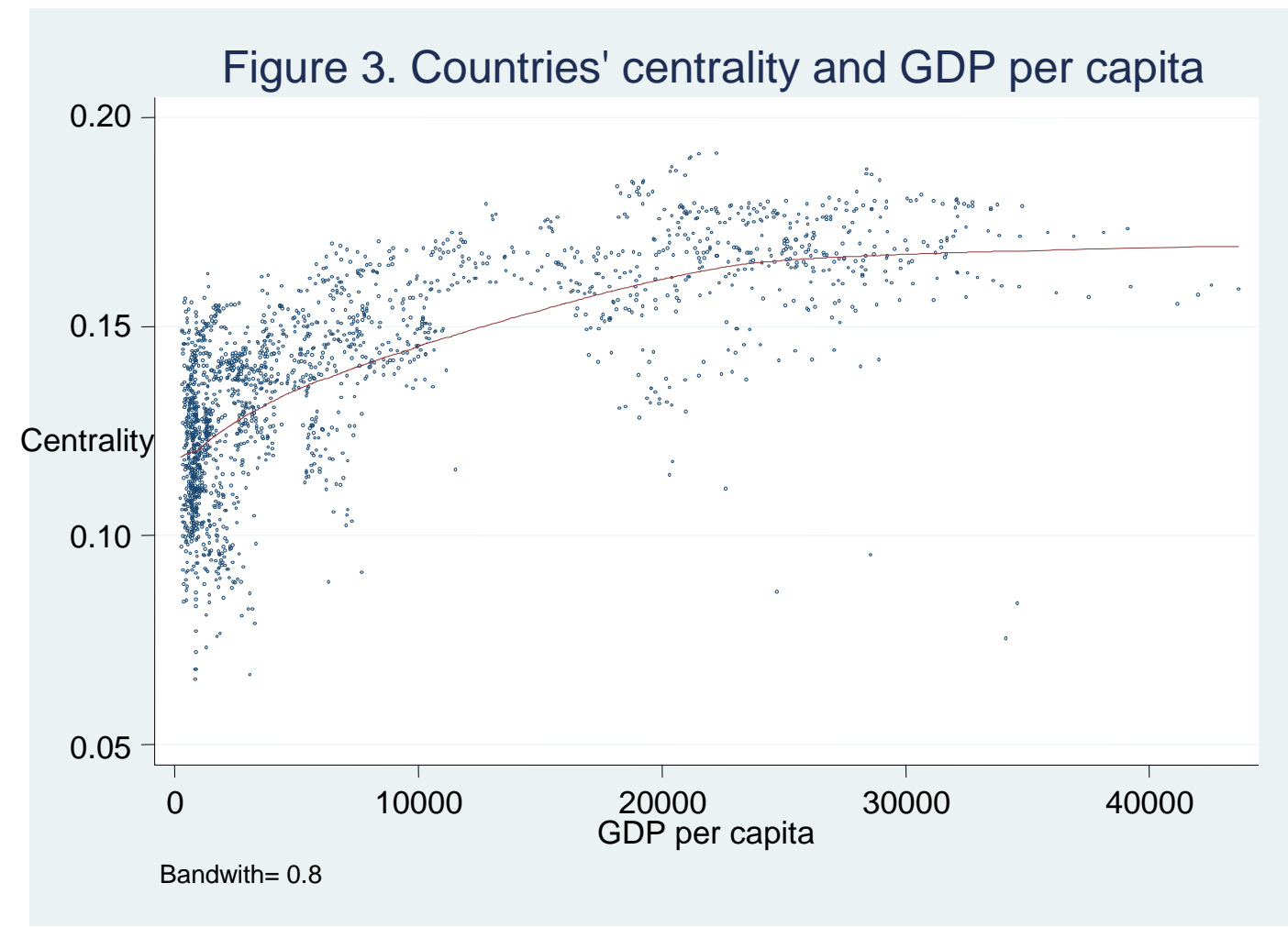


Figure 4a. Herfindahl (Diversification and countries' centrality)

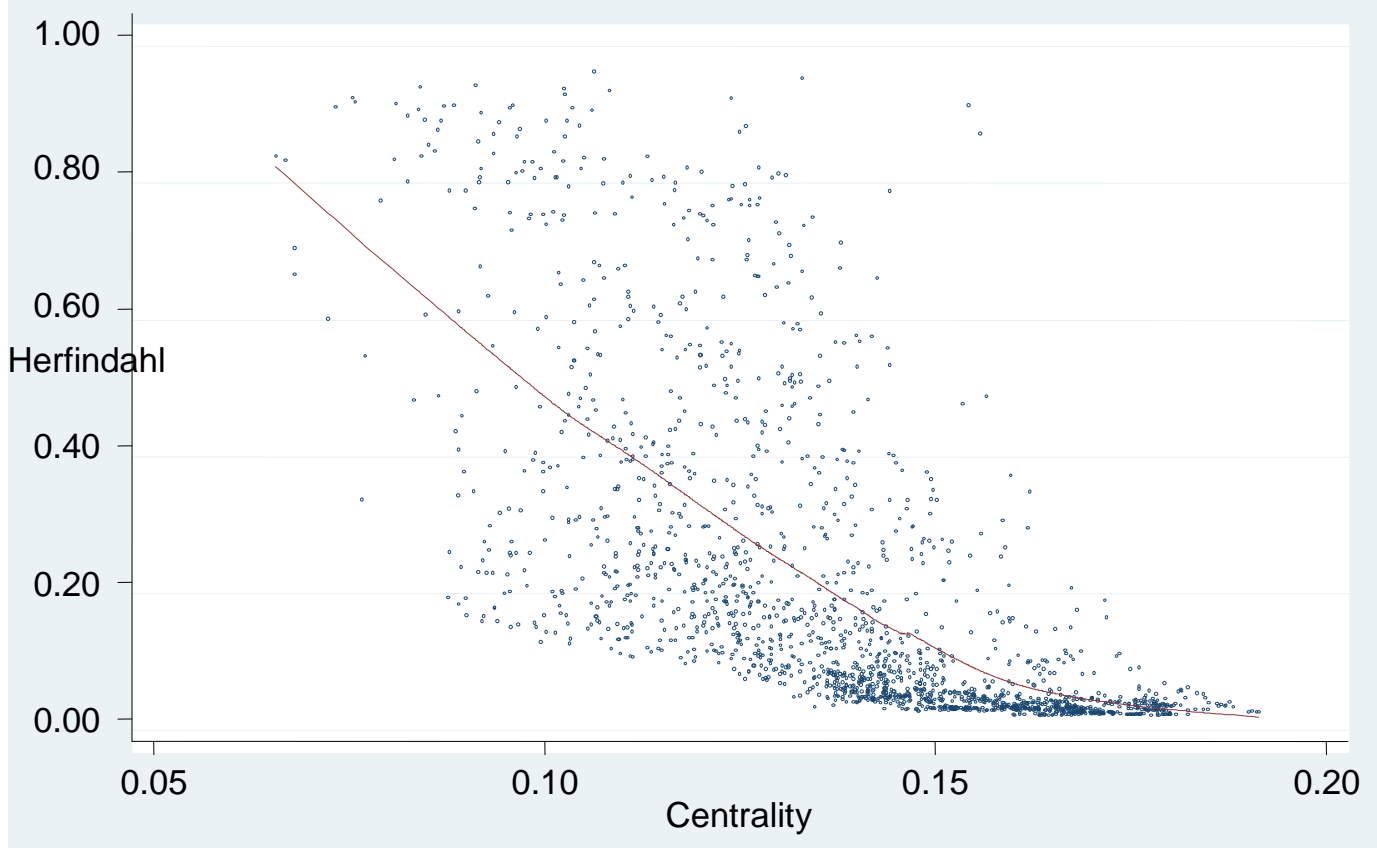

Bandwith $=0.8$

Figure 4b. Gini (Diversification and countries' centrality)

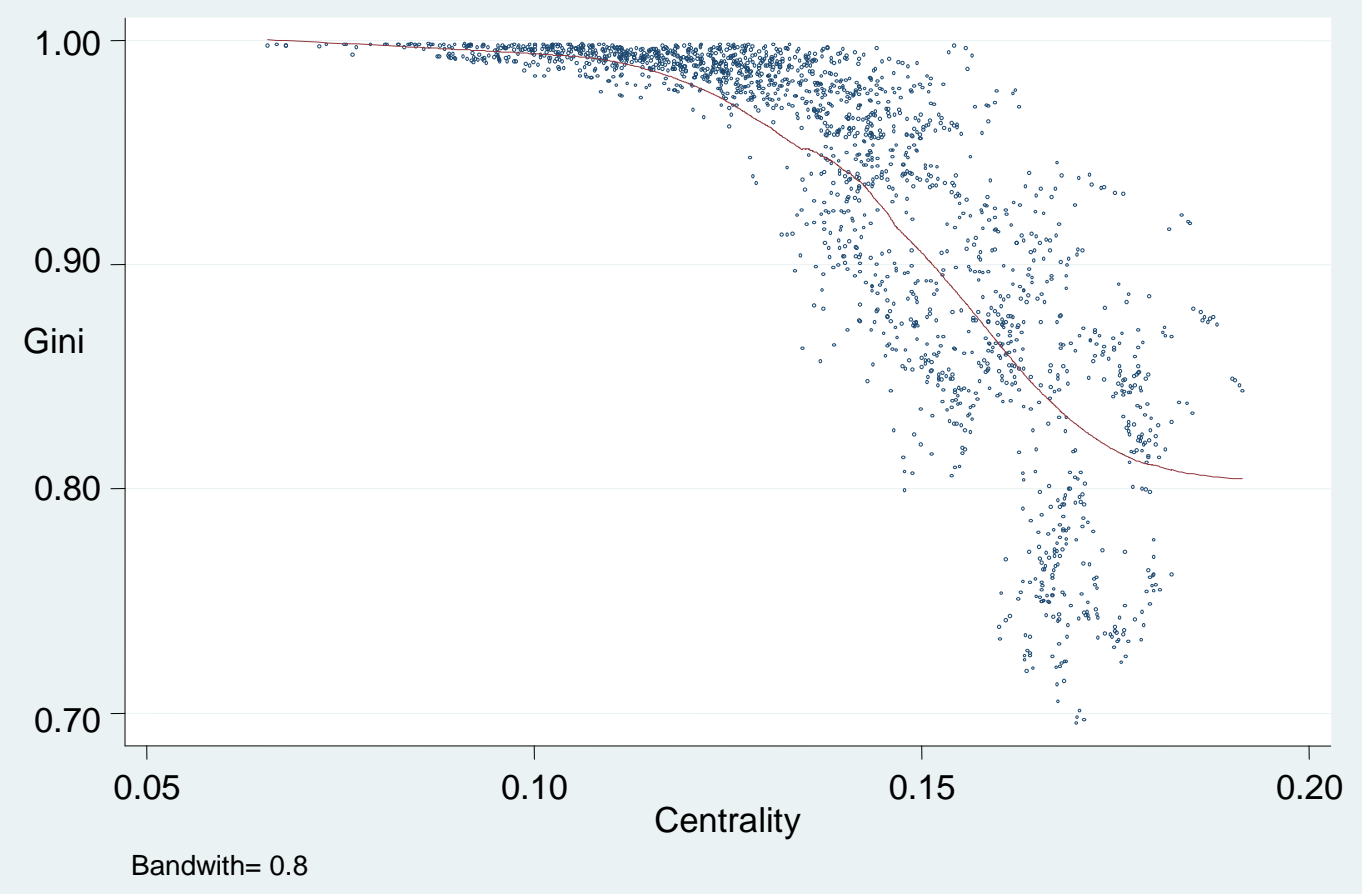

